\title{
Downy mildew on peas (Peronospora viciae f sp pisi)
}

\author{
R Stegmark \\ Box 520, S-267 25 Bjuv, Sweden \\ (Received 12 December 1994; accepted 31 January 1995)
}

\author{
MINISTERE de L'AGRICULTURE

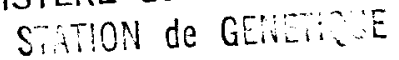

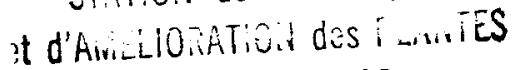 \\ INRA B.V. 1540 \\ 21034 DIJON CEDEX \\ FRANCE
}

\begin{abstract}
Summary - Downy mildew, Peronospora viciae, on peas is widely distributed all over the world. This fungus causes systemic infection of seedlings, local infections on leaves and pod infections. Mycelia and oospores of $P$ viciae can be found in seed coats. However, transmission of the infection from seed to seedling has not been reported. Oospores in the soil are the most important primary inoculum. Conidia can be distributed over long distances. Treatment of seeds with acylalanine fungicides is very effective against systemic seedling infection. There is a variation in resistance to downy mildew among pea varieties. Some varieties have race-specific resistance but there are also varieties with nonrace-specific partial resistance.
\end{abstract}

pea / Peronospora pisi $=$ downy mildew $/$ specific resistance $/$ chemical control / genetic variation

Résumé - Le mildiou du pois, Peronospora viciae f sp pisi. Le mildiou du pois, Peronospora viciae, est largement distribué sur le pois dans le monde entier. Le champignon provoque une infection systémique sur les plantules, des infections localisées sur les feuilles et des infections des gousses. Le mycelium et les oospores de $\mathrm{P}$ viciae peuvent être trouvés sur le tégument de la graine. Cependant la transmission de l'infection de la graine à la plantule n'a pas été signalée. Ce sont les oospores dans le sol qui constituent linoculum primaire le plus important. Les conidies peuvent être dispersées sur de longues distances. Le traitement des semences avec des fongicides à base d'acylaniline est très efficace contre les infections systémiques des plantules. Il existe une variabilité de la résistance entre les variétés de pois. Certaines variétés ont une résistance spécifique à certaines races, mais il y a aussi des variétés possédant une résistance non-spécifique.

pois $/$ Peronospora pisi $=$ mildiou $/$ résistance spécifique $/$ lutte chimique / variabilité génétique

\section{INTRODUCTION}

Downy mildew on peas is caused by Peronospora viciae. This fungus can cause systemic, local leaf infections and pod infections. Downy mildew of peas is widely distributed all over the world (Dixon, 1981).

\section{ECONOMIC SIGNIFICANCE}

\section{Systemic infection}

Systemic infection of seedlings can cause considerable yield loss. Olofsson (1966) and Biddle et al (1988) reported yield losses of $30 \%$ in Sweden and $45 \%$ in UK, respectively.

\section{Local infection}

Local infection on leaves is probably not an important yield-reducing factor. The area of foliage infected per plant has rarely been found to be greater than $15 \%$, although the numbers of infected plants in the field can reach $100 \%$ (Pegg and Mence, 1972). Heavy infection of upper leaves after flowering may reduce the yield. Meadley and Milbourn (1971) showed that a $50 \%$ reduction in solar radiation to the leaves before flowering had no effect on yield, whereas the 
same reduction over the 4 weeks between flowering and harvest reduced the yield by approximately $50 \%$.

\section{Pod infection}

The effect of pod infection on the yield varies among reports. Campbell (1935) reported losses of between 5 and $40 \%$ in Washington. In Wisconsin, severe downy mildew infection occurred as a single isolated event in 1973 (Hagedorn, 1974), where fields with 62-85\% of diseased pods were not unusual. Pods from these fields were seriously affected and produced few peas of poor quality. Pegg and Mence (1972) found $16 \%$ severely infected pods in vining pea crops in UK, but the effect on yield was considered to be negligible. The most serious effect of pod infections is the reduction of pea quality. Hubbeling (Dixon, 1981) reported that seeds from downy mildew infected pods were harder, had lower germinability and a bitter flavour.

\section{Secondary infection}

A side effect of downy mildew infection is secondary infection by other parasites such as Fusarium spp (Dixon, 1981). A significant correlation was found between the proportion of stembase rot (Fusarium spp) and susceptibility to downy mildew in a field trial with different varieties (Stegmark, 1988).

\section{SYMPTOMATOLOGY}

Downy mildew causes different kinds of symptoms on pea plants. Three different infection types with different symptoms can be recognized during a crop cycle.

\section{Systemic infection}

Systemic infection in seedlings causes stunted growth with conidia sporulation, which often covers a major part of the plant surface (figs 1 and 2). This is caused by oospores in the soil which infect germinating seeds. These infections can seriously reduce the plant population. Germinating seedlings cannot be infected by inoculating the roots. However, Ryan (1971)

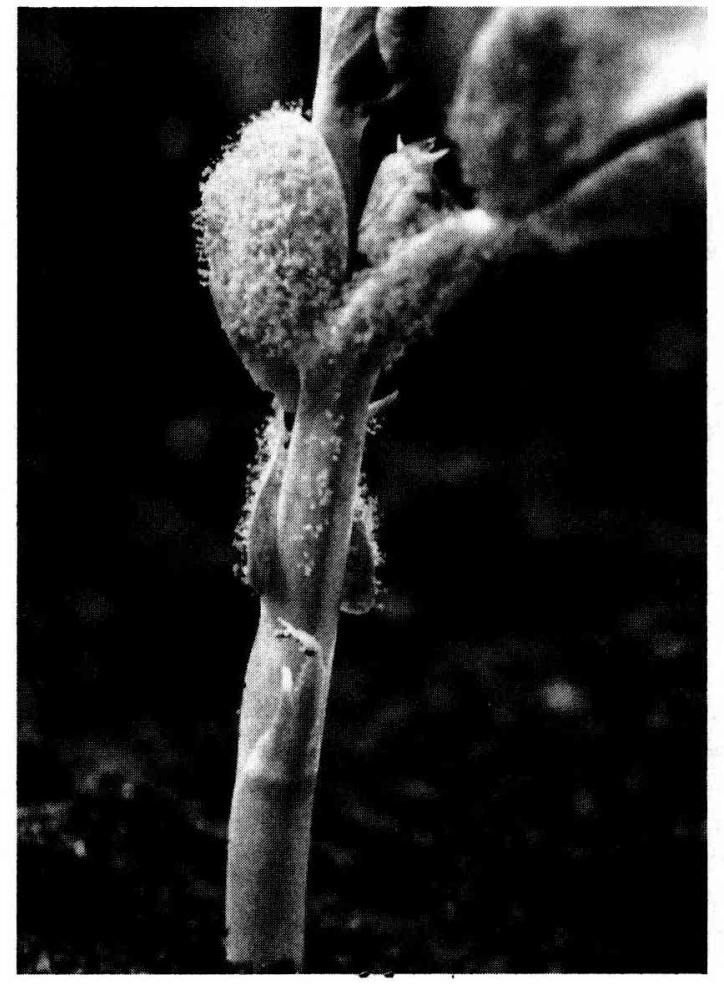

Fig 1. Downy mildew conidia on a systemically infected pea plant.

obtained $90 \%$ systemic infection by placing oospore inoculum around or slightly above the seed. A lower frequency of infection $(50 \%)$ was obtained when placed $3 \mathrm{~cm}$ above the seed level and infection was even more reduced $(1 \%)$ when the oospores were placed $3 \mathrm{~cm}$ below the seeds.

Later in the season, top systemic symptoms can develop with stunting and sporulation occurring over the entire surface of the top of plants. Mence and Pegg (1971) induced systemic infection by inoculating conidia into the apical bud of young plants, or onto the epicotyl or hypocotyl, but not by inoculating the roots of germinating seedlings. Taylor et al (1990) showed that systemic infection could also originate from leaf infection. Top systemic infection is the result of direct infection of the top meristem. This type of infection is found more frequently in varieties with reduced stipule size, determined by the gene st (Matthews and Dow, 1983; Taylor et al, 1990). In these varieties, the top meristem is not protected by the stipules, which wrap around the apex in varieties with normally sized stipules.

Following infection, the mycelium develops in the intercellular spaces penetrating the stem, the leaf stalks, and even the pods through the veins (Kosevskii and Kirik, 1979). 


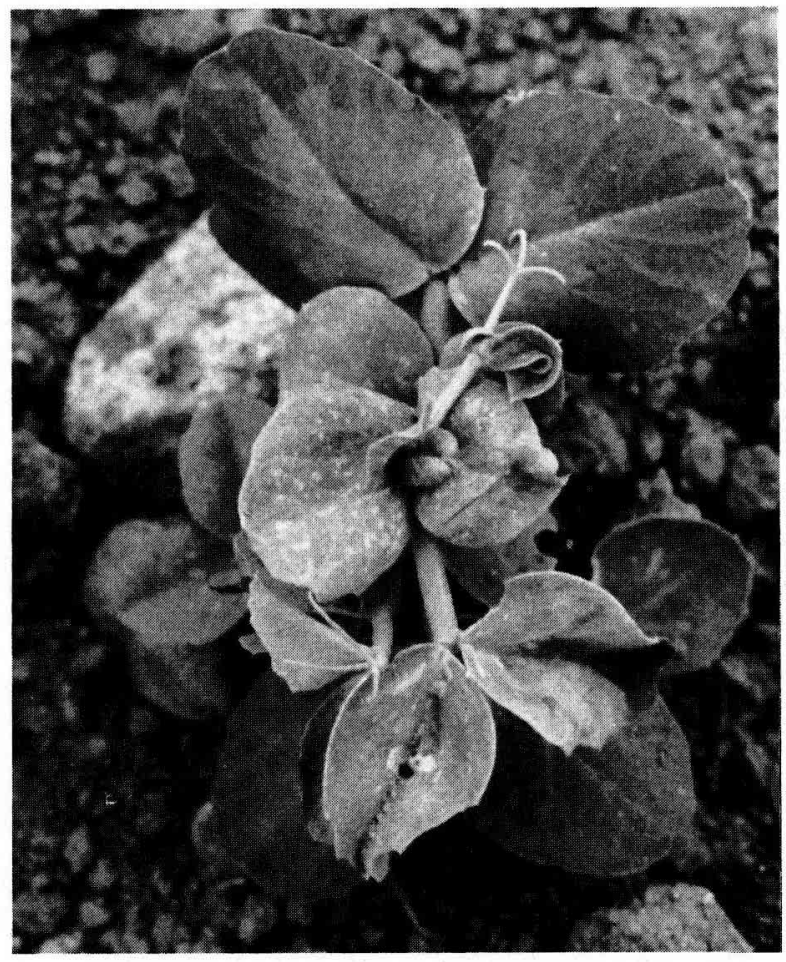

Fig 2. Stunted growth of a systemically infected pea plant.

\section{Local infection}

Local foliar and tendril lesions with conidia sporulation on the abaxial foliar surface is a typical symptom. Local infections on leaves or tendrils develop from conidia present on the plant surface. Germ tubes penetrate the cuticle at an epidermal cell (Mence and Pegg, 1971). These authors did not find appressoria.

Mycelium grows irregularly in the spongy parenchyma of the leaf and under high relative humidity, and often develops between the upper epidermis and the palisade parenchyma. Haustoria are most frequently found in the leaf mesophyll and filiform in epidermal cells; oogonia are terminal, isolated, spherical when mature and pyriform when young (Kosevskii and Kirik, 1979).

\section{Pod infection}

Pod infection causes yellow lesions on the pod surface and epithelial proliferations on the endocarp (Snyder, 1934). Pod infection develops from conidia deposited on young pods rather than by mycelial growth through the peduncle and pedicel (Mence and Pegg, 1971). Oospores are formed within the yellow lesions. Pod infection often causes distorted pods, seed abortion and brown discoloured small peas with a bitter taste (fig 3). Pod infections directly affect pea quality and are therefore a serious expression of the disease.

\section{PATHOGEN INCLUDING PHYSIOLOGIC SPECIALISATION}

\author{
Taxonomy \\ $P$ viciae (Berk) Casp f sp pisi (Sydow) Boerema \\ $\&$ Verhoeven (syn $P$ pisi Sydow) (Perono- \\ sporacea; Oomycetes) causes downy mildew on \\ peas.
}

\section{Spores}

Species of Peronospora produce conidia that lack modification in the apical region, the operculum, do not contain zoospores, and germinate by germ tubes (Shaw, 1981). $P$ viciae also produces oospores, which have a typical reticulate pattern of the exosporium.

\section{Sexual recombination}

The sexual breeding system for $P$ viciae has not been described in literature but may be similar to $P$ parasitica and Bremia lactucae Regel. These species are also capable of regular and predictable production of oospores in large numbers. Both heterothallic and homothallic isolates of these 2 species have been found (McMeekin, 1960; Tommerup, 1981). Sexual reproduction is probably important for the adaptation of the fungus to various host genotypes by recombination of virulence genes. The vegetative stage is probably diploid like in other species of Peronospora (Sansome and Sansome, 1974; Fincham et al, 1979; Tommerup, 1981).

\section{Host range}

The fungus is an obligate parasite which can only grow on living plant tissue. Forma specialis pisi can only infect Pisum species and not species of the genus Vicia within the tribe Vicieae (Sydow, 1921; Campbell, 1935). 


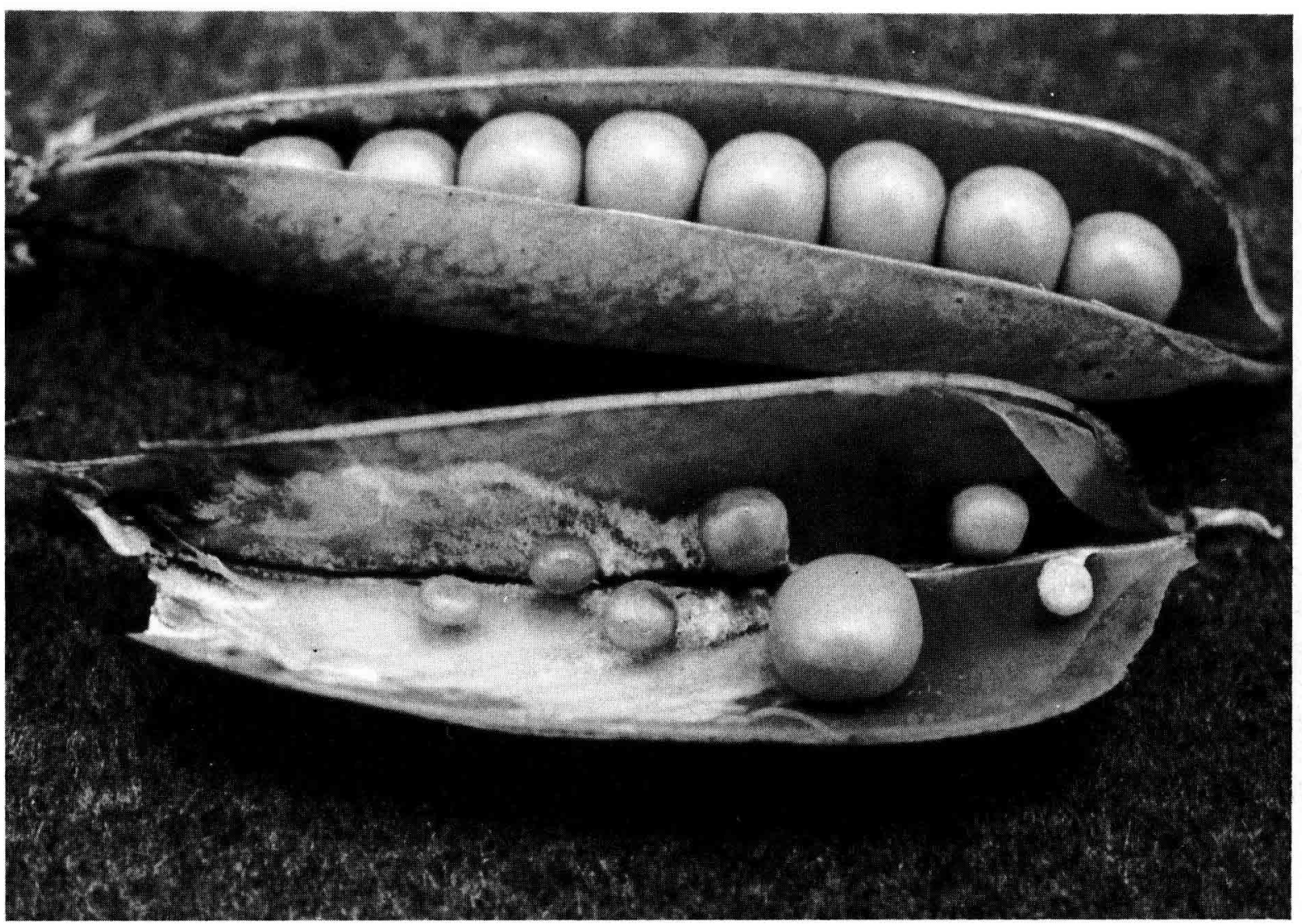

Fig 3. Yellow spots on pod walls, reduced size and brown discolourations of peas caused by downy mildew.

\section{Virulence}

Hubbeling (1975) described variation for virulence in isolates of $P$ viciae in the Netherlands. Five races of the fungus were discriminated by 5 groups of pea genotypes. Three cultivars, 'Starnain', 'Starcovert' and 'Gastro', were resistant to all races. Ester and Gerlagh (1979) later identified 3 new races of the pathogen. 'Race 8' was virulent to all the pea genotypes tested. In Germany, Heydendorff and Hoffman (1978) reported race-specific resistance in cultivars 'Cobri' and 'Puget'. In Britain, Taylor et al (1989) reported a wide range of races. Fifty-five isolates were tested on 10 pea lines. On the basis of 2 differential reactions, namely, symptomless resistance and all other susceptible reactions, 22 groups of isolates were distinguishable.

Virulence to the resistance varieties 'Starcovert', 'Gastro', 'Cobri' and 'Puget' was also found in Scandinavian populations of $P$ viciae (Stegmark, 1990). None of the cultivars 'Cobri', 'Gastro' and 'Starcovert' and other cultivars with similar resistance have been grown in
Scandinavia, so the presence of virulence is not due to local selection pressure. The variety 'Puget' was cultivated for a few years, but not in those fields from which soil-borne inoculum was sampled.

\section{SEED INFECTION}

\section{Seed-borne infection}

Pea seeds do not appear to be an important source of primary inoculum in the field. However, oospores and mycelia have been found in seeds (Melhus, 1931; Heald, 1932; Campbell, 1935; Mence and Pegg, 1971). Mence and Pegg (1971) examined 214 seeds from pods with external lesions, ie from non-systemically infected plants. Three seeds contained oospores and 17 mycelia of $P$ viciae. When these seeds were subsequently germinated, no downy mildew infection resulted. In agreement with this, Hagedorn (1974) did not find any seed-borne infection in 7 seed batches. 


\section{DISEASE CYCLE}

\section{Soil-borne infection}

Oospores in the soil are the primary inoculum early in the season. The oospores can survive for a long time in the soil. Infections are common in south Sweden where a 6 year crop rotation is common practice. Oospores survive for 10-15 years in the soil (Olofsson, 1966). Oospores of $P$ destructor (Berk) Casp in onion debris showed good viability after 25 years of outdoor storage (McKay, 1957).

\section{Wind-distributed conidia}

Conidia distributed by wind from neighbouring fields or more remote growing areas are also important sources of primary inoculum. $P$ tabacina Adam was observed to migrate up to $400 \mathrm{~km}$ per month in the direction of prevailing winds during its introduction phase in the early 1960 s in Europe (Populer, 1981). A much more rapid distribution of this pathogen occurred in USA in 1980 and 1982 , where conidia may have been distributed more than $1000 \mathrm{~km}$ in $2 \mathrm{~d}$ from Texas to Kentucky (Davis and Main, 1986).

Conidia distributed by wind or dispersed by water droplets play an important role in spreading the disease within pea crops. The successive sowing of freezer peas, in different fields, during a period of 1-2 months, favours the development of the disease. Young plants are present in the growing area for a long time compared with crops where all field are sown as early as possible. Young plants are more susceptible than older plants. The results presented in Stegmark (1988) support the view that pea downy mildew primarily infects young tissue. In agreement with Mence and Pegg (1971), terminal embryonic leaves, not yet unfolded at the time of inoculation, were found to be more susceptible than older leaves. Further, an increased resistance was found in older seedlings. This was discovered when seedlings of different ages, ie with 2-6 unfolded nodes, were inoculated in one and the same experiment (Stegmark, 1991).

\section{Partial resistance}

Small changes in partial resistance in the crop can be important since several cycles of infection and sporulation occur in a season.

\section{Temperature and humidity}

The rate of disease progress is very much determined by temperature and relative humidity $(\mathrm{RH})$. Leaf-wetness for a period of at least $3-4 \mathrm{~h}$ is required for infection (Olofsson, 1966; Pegg and Mence, 1970). The temperature may vary between 1 and $24^{\circ} \mathrm{C}$, with an optimum between 12 and $20^{\circ} \mathrm{C}$ (Pegg and Mence, 1970). Initiation and production of conidia requires more than $90 \%$ $\mathrm{RH}$ for at least $12 \mathrm{~h}$ (Olofsson, 1966), and reaches a maximum at $100 \% \mathrm{RH}$ (Pegg and Mence, 1970). Most conidia lose their viability within $3 \mathrm{~d}$ after being shed (Pegg and Mence, 1970).

\section{DETECTION OF SEED-BORNE INFECTION}

Examination of seed coats for presence of mycelium and oospores was used by Melhus (1931) and Mence and Pegg (1971). No other methods to detect seed-borne infection have been described in the literature.

\section{CONTROL}

\section{Fungicides}

Seed dressing with systemic acylalanine fungicides (eg, metalaxyl) is very effective against systemic seedling infections (Brokenshire, 1980). However, later in the season, the pod infection can still be severe. There is no real effective fungicide treatment against pod infection in peas grown for freezing. In the long run, the current acylalanine fungicides may become ineffective due to development of tolerance by the pathogen.

\section{Host resistance}

Variation in resistance between pea cultivars has been reported by Olofsson (1966), Allard (1970), Ryan (1971) and Stegmark (1988). Some cultivars are completely resistant to some isolates but are fully susceptible to others. However, there are also pea genotypes that have stable partial resistance, never complete, to different isolates (Stegmark, 1990).

\section{Complete resistance}

Race-specific resistance was found in several cultivars, but there is no pea genotype with complete 
resistance to all known pathogen races (Ester and Gerlagh, 1979; Matthews and Dow, 1983).

The Pisum Genebank, the Weibullsholm Collection, kindly supplied by Stig Blixt, has been screened for resistance to oospore infection of germinating seeds at Nordreco ( $B$ Jönsson, personal communication, 1980). Only one line ( $\mathrm{L} 1382)$ showed complete resistance in replicated trials when pre-germinated seeds were soaked into a conidia suspension according to a method described by Ryan (1971). This line has red flowers and brown seeds. When the seed coat was removed before sowing, the seedlings became severely infested by downy mildew. This shows that the seed coat contributes to the major part of the resistance in this line.

\section{Partial resistance}

The cultivar 'Dark Skin Perfection' (DSP) is more resistant to downy mildew than some other cultivars used for the production of peas for canning and freezing (Olofsson, 1966; Stegmark, 1988). However, DSP is also affected by downy mildew under conditions favourable to the pathogen. The partial resistance of DSP has been durable for over 30 years and should be maintained in future cultivars.

One pea-breeding line with a high level of partial resistance was described by Stegmark (1988). This line exhibited low susceptibility to all isolates of the fungus, but never complete resistance to any isolate (Stegmark, 1990). The partial resistance is determined by more than 1 gene. A combination of dominant, recessive and intermediate resistance genes are involved (Stegmark, 1992).

\section{REFERENCES}

Allard C (1970) Recherches sur la biologie du mildiou pois. Ann Phytopathol 2, 87-115

Biddle AJ, Knott CM, Gent GP (1988) Pea Growing Handbook. Processors \& Growers Research Organisation, Peterborough, UK, p 264

Brokenshire T (1980) Control of pea downy mildew with seed treatments and foliar sprays. In: Test of Agrochemicals and Cultivars. Vol 1, Suppl Annals of Applied Biology, 64, 34-35

Campbell L (1935) Downy mildew of peas caused by Peronospora pisi (De Bary) Syd. Washington Agric Exp Sta Bull 318, 42
Davis JM, Main CE (1986) Applying atmospheric trajectory analysis to problems in epidemiology. Plant Dis 70, 490-497

Dixon GR (1981) Downy mildews on peas and beans. In: The Downy Mildews (DM Spencer, ed), 87-154, Academic Press, New York, USA, p 636

Ester A, Gerlagh M (1979) Het voorlopig (?) einde van veredeling op fysio-specifieke resistentie tegen valse meeldauw van de erwt. Zaadbelangen 33, 146-147

Fincham JRS, Day PR, Radford A (1979) Fungal Genetics. Blackwell Scientific Publications, Oxford, UK, p 669

Hagedorn DJ (1974) Recent pea anthracnose and downy mildew epiphytotic in Wisconsin. Plant Dis Rep 58, 226-229

Heald FD (1932) Downy Mildew of Pea. Washington Agric Exp Sta Bull 275, 48

Heydendorff RC, Hoffman GM (1978) Zur physiologischen Spezialisierung von Peronospora pisi Syd. $Z$ Pflanzenkr Pflanzenschutz 85, 561-569

Hubbeling $N$ (1975) Resistance of peas to downy mildew and distinction of races of Peronospora pisi Syd. Meded Fac Rijksuniv Landbouwwet Gent 40, 539-543

Kosevkii II, Kirik NN (1979) [Features of the development of mycelium of Peronospora pisi Syd in pea tissue] Osobennosti razvitiya mitseliya Peronospora pisi Syd $v$ tkanyak gorokha. Mikilogiya $i$ Fitopatologiya 13, 46-48

Matthews P, Dow KP (1983) Disease resistance improvement in dried peas. In: 72nd Report 19811982, John Innes Institute, Norwich, UK, p 195

McKay $R$ (1957) The longevity of the oospores of onion downy mildew Peronospora destructor (Berk) Casp. Sci Proc A Dublin Soc Nat Sci 27, 295-307

McMeekin D (1960) The role of the oospores of Peronospora parasitica in downy mildew of crucifers. Phytopathology 50, 93-97

Meadley JT, Milbourn GM (1971) The growth of vining peas. III. The effect of shading on abscission of flowers and pods. J Agric Sci 77, 103-108

Melhus IE (1931) The presence of mycelium and oospores of certain downy mildews in the seeds of their hosts. lowa State College Sci 5, 185-8

Mence MJ, Pegg GF (1971) The biology of Peronospora viciae on pea: factors affecting the susceptibility of plants to local infection and systemic colonization. Ann App/Bio/67, 297-308

Olofsson $J(1966)$ Downy mildew of peas in western Europe. Plant Dis Rep 50, 257-261

Pegg GF, Mence MJ (1970) The biology of Peronospora viciae on pea: laboratory experiments on the effects of temperature, relative humidity and light on production, germination and infectivity of sporangia. Ann App/ Biol 66, 417-428

Pegg GF, Mence MJ (1972) The biology of Peronospora viciae on pea: the development of local and systemic infections and their effect on vining yield. Ann Appl Biol 71, 19-31 
Populer C (1981) Epidemiology of downy mildews. In: The Downy Mildews (DM Spencer, ed), Academic Press, New York, USA, 57-105

Ryan EW (1971) Two methods of infecting peas systemically with Peronospora pisi, and their application in screening cultivars for resistance. Ir J Agric Res 10, 315-322

Sansome E, Sansome FW (1974) Cytology and life history of Peronospora parasitica on Capsella Bursa-pastoris and Lunaria annua. Trans Br Mycol Soc 62, 323-332

Shaw CG (1981) Taxonomy and evolution. In: The Downy Mildews (DM Spencer, ed), 17-29, Academic Press, New York, USA, p 636

Snyder WC (1934) Peronospora viciae and internal proliferation in pea pods. Phytopathology 24, 1358-1365

Stegmark R (1988) Downy mildew resistance of various pea genotypes. Acta Agric Scand 38, 373-379

Stegmark R (1990) Variation for virulence among Scaninavian isolates of Peronospora viciae f $\mathrm{sp}$ pisi (pea downy mildew) and response of pea genotypes. Plant Pathol 39, 118-124

Stegmark R (1991) Comparison of different inoculation techniques to screen resistance of pea lines to downy mildew. J Phytopathol 133, 209-215

Stegmark R (1992) Diallel analysis of the inheritance of partial resistance to downy mildew in peas. Plant Breed 108, 111-117

Sydow H (1921) Mycotheca germanica, Fasc XXIXXXXVI (No 1 401-1 800). Ann Mycol 19, 133-144

Taylor PN, Lewis BG, Matthews P (1989) Pathotypes of Peronospora viciae in Britain. J Phytopathol 127, 100-106

Taylor PN, Lewis BG, Matthews P (1990) Factors affecting systemic infection of Pisum sativum by Peronospora viciae. Mycol Res 94, 179-181

Tommerup IC (1981) Cytology and genetics of downy mildews. In: The Downy Mildews (DM Spencer, ed), Academic Press, New York, USA, 121-142 